\title{
FAKTOR-FAKTOR YANG MEMPENGARUHI PERKEMBANGAN MOTORIK PADA BALITA USIA 4-5 TAHUN DI TK SISWA HARAPAN CILIWUNG SURABAYA
}

\author{
Eny Astuti* \\ STIKES William Booth Surabaya, Jln. Cimanuk No. 20, Telp. (031) 5633365 \\ enyastutiserang@gmail.com
}

\begin{abstract}
ABSTRAK
Perkembangan anak yang optimal tergantung pada berkembangnya kemampuan dan ketrampilan motorik, baik motorik kasar maupun halus. Namun tidak semua balita dapat berkembang seperti yang seharusnya, terkadang ada balita yang lambat atau menyimpang dari kemampuan yang seharusnya dimiliki pada tahapan usianya. Proses perkembangan motorik dipengaruhi oleh beberapa faktor yaitu motivasi belajar anak, pengetahuan ibu, lingkungan pengasuhan, teman sebaya, stimulasi, tingkat gizi. Penelitian ini bertujuan untuk mengetahui faktor-faktor yang mempengaruhi perkembangan motorik pada balita usia 4-5 tahun di TK Siswa Harapan Ciliwung Surabaya. Penelitian dilakukan menggunakan metode deskriptif korelatif dengan populasi balita usia 4-5 tahun beserta orang tuanya, yang berjumlah 20 orang. Sampel berjumlah 19 orang yang diambil menggunakan teknik purposive sampling. Teknik analisis data dengan menggunakan distribusi frekuensi dan tabulasi silang. Pengumpulan data dengan menggunakan kuisioner dan lembar DDST. Hasil penelitian menunjukan bahwa faktor-faktor yang mempengaruhi perkembangan motorik pada balita usia 4-5 tahun adalah faktor gizi, faktor lingkungan, dan faktor stimulasi. Sedangkan faktor yang tidak mempengaruhi adalah faktor pengetahuan. Disarankan pihak TK dapat bekerja sama dengan instansi kesehatan untuk meningkatkan peran orang tua dalam memantau perkembangan motorik pada balitanya.
\end{abstract}

Kata Kunci : Perkembangan motorik, balita.

\section{Pendahuluan}

Setiap orang tua pasti mempunyai harapan agar balitanya dapat tumbuh dan berkembang secara optimal. Tercapainya perkembangan yang optimal tergantung pada potensi biologis yang ditandai dengan berkembangnya kemampuan dan ketrampilan motorik, baik motorik kasar maupun halus. Perkembangan motorik merupakan perkembangan kontrol pergerakan badan melalui koordinasi aktivitas saraf pusat, saraf tepi dan otot (Soetjiningsih, 2013). Perkembangan motorik ini sejalan dengan bertambahnya usia secara bertahap dan berkesinambungan, misalnya pada usia 4-5 tahun mereka sudah bisa menggambar mengikuti bentuk, menulis sendiri, melompat dengan 1 kaki, dan lain-lain. Pada usia 4-5 tahun merupakan masa keemasan (golden period), atau jendela kesempatan (window of opportunity), dan masa kritis (cristical period) (Mahayaty, 2014), sebagai periode terpenting dalam tumbuh kembang. Namun tidak semua balita dapat berkembang seperti yang seharusnya, terkadang ada balita yang lambat atau menyimpang dari kemampuan yang seharusnya dimiliki pada tahapan usianya, kondisi seperti ini kadang tidak dipahami oleh para orang tua, biasanya orang tua baru menyadari setelah segalanya sudah terlambat. Proses perkembangan motorik pada balita dapat dipengaruhi oleh beberapa faktor yaitu motivasi belajar anak, pengetahuan ibu, lingkungan pengasuhan, teman sebaya, stimulasi, tingkat gizi. Dari 6 orang tua yang di tanya tentang perkembangan motorik seperti pengetahuan orang tua pada balita usia 4-5 tahun, apakah anak harus sudah bisa menggambar 2 bagian manusia, 3 orang menjawab tidak mengetahui jika pada usia 4-5 tahun balita harus bisa menggambar 2 bagian manusia, dan ketika ditanya apakah ibu melatih anak untuk belajar menggambar dan menulis, bagaimana asupan gizi yang di makan anak, apa yang dilakukan ibu ketika anak tidak mau sekolah, 2 orang menjawab mereka tidak melatih anakmya untuk belajar menggambar dan menulis, 3 orang menjawab jika anaknya lebih suka makan yang makanan instan (mie instan, sosis) dan 1 orang membiarkan anak jika tidak mau sekolah. Padahal faktor pengetahuan ibu, stimulasi, asupan gizi dan lingkungan pengasuhan dapat mempengaruhi perkembangan balita. 
Penyimpangan perkembangan dapat terjadi setiap anak, di Indonesia ditemukan 5\% dari jumlah balita yang mengalami penyimpangan perkembangan (Ario, 2012), sedangkan untuk daerah Jawa Timur diperkirakan 44 balita yang mengalami penyimpangan perkembangan pada setiap Kabupaten yang ada. Untuk data di RSUD. Dr. Soetomo Surabaya dari 37.960 total kunjungan pasien balita di poli anak 2,22\% mengalami penyimpangan perkembangan (Suryawan, 2010). Observasi awal yang di lakukan peneliti di TK Siswa Harapan terdapat 20 anak yang berusia 4-5 tahun. Dalam wawancara dengan salah satu guru TK tersebut, terdapat 5 siswa berusia 4-5 tahun yang perkembangan motorik halusnya terlambat seperti belum bisa memegang pensil dengan baik dan belum bisa menulis sendiri. Menurut Fida dan Maya (2012) perkembangan motorik berdasarkan tahapan usianya seharusnya anak usia 4 tahun sudah bisa menggambar mengikuti bentuk dan menggambar manusia, melompat dengan 1 kaki. Berdasarkan data diatas dan pengamatan penulis terlihat bahwa angka meragukan dan penyimpangan perkembangan masih cukup besar.

Tidak banyak orang tua yang mengerti bahwa keterampilan motorik halus dan kasar seorang balita perlu dilatih dan dikembangkan setiap saat dengan berbagai aktivitas (Lismadiana, 2014). Apabila kemampuan motorik masa ini berkembang dengan baik, maka perkembangan berikutnya akan baik pula, begitu juga sebaliknya. Menurut Hurlock (1998) perkembangan motorik yang normal memungkinkan balita dapat bermain atau bergaul dengan teman sebayanya, sedangkan yang tidak normal akan menghambat anak untuk bergaul bahkan dia akan dikucilkan atau menjadi anak yang terpinggirkan. Keterlambatan atau penyimpangan lebih sering disebabkan oleh kurangnya untuk mempelajari keterampilan motorik, perlindungan orang tua yang berlebihan, asupan nutisi yang kurang, pengetahuan dan pemahaman tentang perkembangan balita sudah harus di miiki oleh orang tua sejak balita tersebut masih dalam usia dini. Oleh karena itu ketelitian orang tua sangat diperlukan sebab untuk mencapai perkembangan optimal, seluruh potensi yang dimiliki anak dapat distimulasi oleh orang tua. Sebelum melakukan stimulasi, orang tua memerlukan bekal pengetahuan tentang stimulasi, memberikan nutrisi yang seimbang pada anak dan anak dalam lingkungan pengasuhan yang baik, karena semua ini merupakan faktor pendukung dalam perkembangan motorik anak.
Untuk mengurangi dampak keterlambatan motorik, peran orang tua dan tenaga kesehatan dalam mendukung perkembangan motorik balitanya sangatlah penting. Tenaga kesehatan dapat memberikan Heald Education kepada orang tua terutama ibu tentang perkembangan motorik dapat tumbuh secara optimal bila orang tua mempunyai pengetahuan yang baik yaitu mengetahui pengertian, tahapan dan faktorfaktor yang mempengaruhi perkembangan motorik, memberikan asupan gizi yang adekuat, menstimulasi yang terarah dan berkesinambungan dengan metode bermain dan kasih sayang, serta balita berada pada lingkungan yang baik untuk menentukan tercapai atau tidaknya potensi yang telah dimiliki oleh anak. Selain itu tenaga kesehatan dapat memantau perkembangan motorik balita dengan menggunakan metode Denver Developmental Screening Test (DDST). Sehingga orang tua dapat memantau perkembangan motorik pada balitanya dalam kehidupan sehari-hari.

\section{Metode}

Beradasarkan tujuan dalam penelitian ini metode penelitian yang digunakan adalah deskriptif korelatif, yaitu Metode penelitian deskriptif korelatif digunakan untuk menggambarkan hubungan antar variabel. Pada penelitian ini peneliti ingin menggambarkan faktor-faktor yang mempengaruhi perkembangan motorik balita di TK Siswa Harapan Ciliwung Surabaya yaitu faktor gizi, lingkungan pengasuhan, stimulasi dan pengetahuan. Populasi dalam penelitian ini seluruh orang tua yang memiliki balita dan balita usia 4 - 5 tahun di TK Siswa Harapan, Ciliwung Surabaya. Peneliti menetapkan populasi 20 orang $(\mathrm{N}=20)$. Dalam penelitian ini peneliti mengambil sampel orang tua yang memiliki balita dan balita usia $4-5$ tahun di TK Siswa Harapan, Ciliwung Surabaya.dan Kriteria sampel dalam penelitian adalah : Orang tua (ayah atau ibu) yang tinggal serumah dengan balitanya, Orang tua dan balita yang bersedia menjadi responden, dan Orang tua yang bisa membaca dan menulis. Dalam penelitian ini menggunakan teknik sampling non probability sampling dengan cara purposive sampling yaitu teknik penentuan sampel dengan cara memilih sampel diantara populasi sesuai dengan yang dikehendaki peneliti. Variabel bebas dalam penelitian ini adalah faktor-faktor yang mempengaruhi perkembangan motorik (faktor gizi, lingkungan pengasuhan, stimulasi dan pengetahuan). Dan Variabel terikat dalam 
penelitian adalah perkembangan motorik balita usia 4-5 tahun. Alat ukur yang dipakai untuk menilai perkembangan motorik balita usia 4-5 tahun dengan DDST dan pakai kuesioner untuk mengukur faktor-faktor yang mempengaruhi perkembangan motorik balita usia 4-5 yahun yang berupa Gizi, lingkungan pengasuhan, Stimulasi dan Pengetahuan.

\section{Hasil Penelitian}

Hasil pengumpulan data tentang Faktor-Faktor Yang Memengaruhi perkembangan motorik (faktor gizi, lingkungan pengasuhan, stimulasi dan pengetahuan), adalah sebagai berikut.

3.1 Karakteristik Responden berdasarkan jenis kelamin

Tabe1 3.1. Karakteristik Responden Berdasarkan Umur

\begin{tabular}{|c|c|c|c|}
\hline No. & Umur & Jml Resp & Prosentase \\
\hline 1 & $<25$ Tahun & 3 & $15.8 \%$ \\
\hline 2 & 26-30 Tahun & 4 & $21 \%$ \\
\hline 3 & 31-35 Tahun & 6 & $31.6 \%$ \\
\hline 4 & $\geq 36$ Tahun & 6 & $31.6 \%$ \\
\hline \multicolumn{2}{|r|}{ Jumlah } & 19 & $100 \%$ \\
\hline
\end{tabular}

Berdasarakan Tabe1 3.1 di atas menunjukkan bahwa karakteristik orang tua responden berdasarkan umur sebagian besar berumur 31-35 tahun dan $\geq 36$ tahun yaitu masing-masing sebanyak 6 responden $(31,6 \%)$.

3.2 Karakteristik Responden berdasarkan Jenis Kelamin

Tabe1 3.2. Karakteristik Responden Berdasarkan Jenis Kelamin.

\begin{tabular}{|c|l|c|c|}
\hline No. & \multicolumn{1}{|c|}{$\begin{array}{c}\text { Kenis } \\
\text { Kelamin }\end{array}$} & Jml Resp & Prosentase \\
\hline 1 & Perempuan & 15 & $78.9 \%$ \\
\hline 2 & Laki-laki & 4 & $21.1 \%$ \\
\hline \multicolumn{2}{|c|}{ Jumlah } & 19 & $100 \%$ \\
\hline
\end{tabular}

Berdasarkan tabel 3.2 dapat diketahui hasil karakteristik orang tua responden berdasarkan jenis kelamin sebagian besar berjenis kelamin perempuan yaitu sebanyak 15 responden $(78,9$ $\%)$.

3.3 Karakteristik Responden berdasarkan Pendidikan
Tabe1 3.3.Karakteristik Responden Berdasarkan Pendidikan

\begin{tabular}{|c|l|c|c|}
\hline No. & \multicolumn{1}{|c|}{ Pendidikan } & Jml Resp & Prosentase \\
\hline 1 & Tidak Sekolah & 0 & 0 \\
\hline 2 & SD & 1 & $5.3 \%$ \\
\hline 3 & SMP & 0 & 0 \\
\hline 4 & SLTA & 13 & $68.4 \%$ \\
\hline 5 & Perguruan Tinggi & 5 & $26.3 \%$ \\
\hline \multicolumn{2}{|c|}{ Jumlah } & 19 & $100 \%$ \\
\hline
\end{tabular}

Berdasarkan tabel 3.3 dapat diketahui hasil karakteristik orang tua responden berdasarkan pendidikan sebagian besar SLTA yaitu sebanyak 13 responden $(68,4 \%)$.

3.4 Karakteristik Responden berdasarkan Pekerjaan.

Tabe1 3.4.Karakteristik Responden Berdasarkan Pekerjaan

\begin{tabular}{|c|l|c|c|}
\hline No. & \multicolumn{1}{|c|}{ Pekerjaan } & Jml Resp & Prosentase \\
\hline 1 & $\begin{array}{l}\text { Tidak } \\
\text { Bekerja/IRT }\end{array}$ & 2 & $10.5 \%$ \\
\hline 2 & Wiraswasta & 5 & $26.3 \%$ \\
\hline 3 & Peg Negeri & 0 & 0 \\
\hline 4 & Swasta & 12 & $63.2 \%$ \\
\hline \multicolumn{2}{|c|}{ Jumlah } & 19 & $100 \%$ \\
\hline
\end{tabular}

Berdasarkan tabel 3.4 dapat diketahui hasil karakteristik orang tua responden berdasarkan pekerjaan sebagian besar bekerja sebagai pegawai swasta yaitu sebanyak 12 orang $(63,2 \%)$.

3.5 Karakteristik Responden berdasarkan Jumlah Anak.

Tabe1 3.5.Karakteristik Responden Berdasarkan Jumlah Anak

\begin{tabular}{|c|l|c|c|}
\hline No. & Jml Anak & Jml Resp & Prosentase \\
\hline 1 & Satu & 6 & $31.6 \%$ \\
\hline 2 & Dua & 2 & $10.5 \%$ \\
\hline 3 & Tiga & 11 & $57.9 \%$ \\
\hline 4 & $>$ Tiga & 0 & 0 \\
\hline \multicolumn{2}{|c|}{ Jumlah } & 19 & $100 \%$ \\
\hline
\end{tabular}

Berdasarkan tabel 3.5 dapat diketahui hasil karakteristik orang tua responden berdasarkan jumlah anak sebagian besar jumlah anak dalam keluarga tiga orang yaitu sebanyak 11 responden $(57,9 \%)$.

3.6 Karakteristik Responden berdasarkan Faktor Gizi 
Tabe1 3.6.Karakteristik Berdasarkan Faktor Gizi

\begin{tabular}{|c|l|c|c|}
\hline No. & Faktor Gizi & Jml Resp & Prosentase \\
\hline 1 & Baik & 8 & $42.1 \%$ \\
\hline 2 & Cukup & 8 & $42.1 \%$ \\
\hline 3 & Kurang & 3 & $15.8 \%$ \\
\hline \multicolumn{2}{|c|}{ Jumlah } & 19 & $100 \%$ \\
\hline
\end{tabular}

Berdasarkan tabel 3.6 dapat diketahui responden mayoritas dengan status gizi baik dan cukup, masing-masing gizi baik sebanyak 8 responden $(42,1 \%)$.

3.7 Karakteristik Responden Berdasarkan Faktor Lingkungan Pengasuhan

Tabel 3.7. Karakteristik Responden Berdasarkan Faktor Lingkungan Pengasuhan

\begin{tabular}{|c|l|c|c|}
\hline No. & $\begin{array}{c}\text { Faktor Lingk } \\
\text { Pengas }\end{array}$ & Jml Resp & Prosentase \\
\hline 1 & Demokratis & 14 & $73.7 \%$ \\
\hline 2 & Otoriter & 3 & $15.8 \%$ \\
\hline 3 & Permisif & 2 & $10.5 \%$ \\
\hline \multicolumn{2}{|c|}{ Jumlah } & 19 & $100 \%$ \\
\hline
\end{tabular}

Berdasarkan tabel 3.7 dapat diketahui responden mayoritas dengan status lingkungan pengasuhan yang menggunakan pola asuh demokratis, sebanyak 14 responden $(73,7 \%)$.

3.8 Karakteristik Responden Berdasarkan Faktor Stimulasi

Tabel 3.8. Karakteristik Responden Berdasarkan Faktor Stimulasi

\begin{tabular}{|c|l|c|c|}
\hline No. & $\begin{array}{c}\text { Faktor } \\
\text { Stimulasi }\end{array}$ & Jml Resp & Prosentase \\
\hline 1 & Baik & 7 & $36.8 \%$ \\
\hline 2 & Cukup & 7 & $36.8 \%$ \\
\hline 3 & Kurang & 5 & $26.3 \%$ \\
\hline \multicolumn{2}{|c|}{ Jumlah } & 19 & $100 \%$ \\
\hline
\end{tabular}

Berdasarkan tabel 3.8 dapat diketahui responden mayoritas dengan status stimulasi yang baik dan cukup, masing-masing sebanyak 7 responden $(36,8 \%)$.

\subsection{Karakteristik Responden Berdasarkan Pengetahuan}

Tabel 3.9 Karakteristik Responden Berdasarkan Pengetahuan

\begin{tabular}{|l|c|c|c|}
\hline No. & $\begin{array}{c}\text { Faktor } \\
\text { Pengetahuan }\end{array}$ & Jml Resp & Prosentase \\
\hline
\end{tabular}

\begin{tabular}{|c|l|c|c|}
1 & Baik & 3 & $15.8 \%$ \\
\hline 2 & Cukup & 3 & $15.8 \%$ \\
\hline 3 & Kurang & 13 & $68.4 \%$ \\
\hline \multicolumn{2}{|c|}{ Jumlah } & 19 & $100 \%$ \\
\hline
\end{tabular}

Berdasarkan tabel 3.9 dapat diketahui responden mayoritas dengan status pengetahuan yang kurang, sebanyak 13 responden $(68,4 \%)$.

3.10 Karakteristik Responden Berdasarkan Perkembangan Motorik

Tabel 3.10. Karakteristik Responden Berdasarkan Perkembangan Motorik

\begin{tabular}{|c|l|c|c|}
\hline No. & $\begin{array}{c}\text { Perkembangan } \\
\text { Motorik }\end{array}$ & $\begin{array}{c}\text { Jml } \\
\text { Resp }\end{array}$ & Persen (\%) \\
\hline 1 & Normal & 5 & $26.3 \%$ \\
\hline 2 & Suspect & 11 & $57.9 \%$ \\
\hline 3 & Untestabel & 3 & $15.8 \%$ \\
\hline & Jumlah & 19 & $100 \%$ \\
\hline
\end{tabular}

Berdasarkan tabel 3.10 dapat diketahui responden mayoritas dengan status perkembangan motorik suspect, sebanyak 11 responden $(57,9 \%)$.

3.11 Tabulasi Silang Antara Faktor Gizi Dengan Perkembangan Motorik Pada Balita Usia 4-5 Tahun

Tabel 3.11. Tabulasi Silang Antara Faktor Gizi Dengan Perkembangan Motorik Pada Balita

Usia 4-5 Tahun TK Siswa Harapan CiliwungSurabaya

\begin{tabular}{|l|c|c|c|c|}
\hline \multicolumn{1}{|c|}{$\begin{array}{c}\text { Perkem. } \\
\text { Motorik } \\
\text { Gizi }\end{array}$} & \multirow{2}{*}{ Normal } & Suspect & Untestabel & \multirow{2}{*}{ Total } \\
\cline { 3 - 4 } & & & & \\
\hline Baik & $3(37,5 \%)$ & $4(50 \%)$ & $1(12,5 \%)$ & 8 \\
\hline Cukup & $2(25 \%)$ & $5(62,5 \%)$ & $1(12,5 \%)$ & 8 \\
\hline Kurang & 0 & $2(66,7 \%)$ & $1(12,5 \%)$ & 3 \\
\hline Total & 5 & 11 & 3 & 19 \\
\hline
\end{tabular}

Dari Hasil tabulasi silang diatas yang paling banyak adalah responden yang mengalami perkembangan motorik suspect (meragukan) memiliki status gizi kurang sebanyak 2 responden $(66,7 \%)$.

3.12 Tabulasi Silang Antara Faktor Lingkungan Pengasuhan Dengan Perkembangan Motorik Pada Balita Usia 4 -5 Tahun 
Tabel 3.12. Tabulasi Silang Antara Faktor Lingkungan Pengasuhan Dengan Perkembangan Motorik Pada Balita Usia 4-5 Tahun TK Siswa Harapan CiliwungSurabaya

\begin{tabular}{|l|c|c|c|c|}
\hline $\begin{array}{c}\text { Perkem. } \\
\text { Motorik }\end{array}$ & Normal & Suspect & Untestabel & Total \\
\hline Demokratis & $4(28,6 \%)$ & $8(57,1 \%)$ & $2(14,3 \%)$ & 14 \\
\hline Otoriter & $1(33,3 \%)$ & $2(66,75)$ & $0(0 \%)$ & 3 \\
\hline Permisif & $0(0 \%)$ & $1(50 \%)$ & $1(50 \%)$ & 2 \\
\hline Total & 5 & 11 & 3 & 19 \\
\hline \multicolumn{5}{|c|}{ tabulasi }
\end{tabular}
didapatkan hasil karakteristik responden yang paling banyak memiliki lingkungan pengasuhan yang menggunakan pola asuh otoriter dengan perkembangan motorik suspect (meragukan) sebanyak 2 responden $(66,7 \%)$.

3.13 Tabulasi Silang Antara Faktor Stimulasi Dengan Perkembangan Motorik Balita Usia 4 -5 Tahun

Tabel 3.13Tabulasi Silang Antara Faktor Stimulasi Dengan Perkembangan

Motorik Pada Balita Usia 4-5 Tahun TK Siswa Harapan Ciliwung-Surabaya

\begin{tabular}{|l|c|c|c|c|}
\hline $\begin{array}{c}\text { Perkem. } \\
\text { Motorik } \\
\text { Stimulasi }\end{array}$ & Normal & Suspect & Untestabel & Total \\
\hline Baik & $2(28,6 \%)$ & $4(57,1 \%)$ & $1(14,3 \%)$ & 7 \\
\hline Cukup & $2(28,6 \%)$ & $3(42,8 \%)$ & $2(28,6 \%)$ & 7 \\
\hline Kurang & $1(20 \%)$ & $4(80 \%)$ & $0(0 \%)$ & 5 \\
\hline Total & 5 & 11 & 3 & 19 \\
\hline
\end{tabular}

Hasil dari tabulasi silang diatas yang paling banyak adalah responden yang mengalami perkembangan motorik suspect (meragukan) dengan stimulasi kurang sebanyak 4 responden $(80 \%)$.

3.14 Tabulasi Silang Antara Faktor Pengetahuan Dengan Perkembangan Motorik Balita Usia 4 -5 Tahun

Tabel 3.14 Tabulasi Silang Antara Faktor Pengetahuan Dengan Perkembangan Motorik Pada Balita Usia 4-5 Tahun TK Siswa Harapan Ciliwung-Surabaya.

\begin{tabular}{|l|l|l|l|l|}
\hline $\begin{array}{l}\text { Perkem. } \\
\text { Motorik } \\
\text { Pengetahuan }\end{array}$ & Normal & Suspect & Untestabel & Total \\
\hline
\end{tabular}

\begin{tabular}{|l|c|c|c|c|}
\hline Baik & $0(0 \%)$ & $2(66,7 \%)$ & $1(33,3 \%)$ & 3 \\
\hline Cukup & $0(0 \%)$ & $3(100 \%)$ & $0(0 \%)$ & 3 \\
\hline Kurang & $5(38,5 \%)$ & $6(46,2 \%)$ & $2(15,3 \%)$ & 13 \\
\hline Total & 5 & 11 & 3 & 19 \\
\hline
\end{tabular}

Hasil dari tabulasi silang diatas didapatkan hasil karakteristik responden yang memiliki pengetahuan baik dengan perkembangan motorik normal yaitu tidak ada responden, sedangkan pengetahuan kurang dengan perkembangan motorik normal yaitu 5 responden $(38,5 \%)$. Dari data diatas dapat diambil kesimpulan bahwa faktor pengetahuan tidak mempengaruhi perkembangan motorik pada balita usia 4-5 tahun.

\section{Pembahasan}

Pada pembahasan akan diuraikan hasil penelitian mengenai Gambaran Faktor-Faktor Yang Mempengaruhi Perkembangan Motorik Pada Balita Usia 4-5 Tahun Di TK Siswa Harapan Ciliwung-Surabaya. Berdasarkan tabel 3.6 sampai tabel 3.10 didapatkan hasil tentang karakteristik responden berdasarkan faktor gizi bahwa murid di TK Siswa Harapan Ciliwung Surabaya mayoritas memiliki gizi baik dan cukup sebanyak 8 responden (42.1\%), sedangkan faktor lingkungan pengasuhan kebanyakan menggunakan pola asuh demokratis sebanyak 14 responden (73.7\%), jika dilihat dari pemberian stimulasi mayoritas dengan status stimulasi baik dan cukup sebanyak 7 responden (36.8\%), apabila dilihat dari faktor pengetahuan mayoritas pengetahuan ibu kurang sebanyak 13 responden (68.4\%), jika dari perkembangan motorik pada balita di TK tersebut mayoritas dengan status perkembangan motorik suspect sebanyak 11 responden $(57.9 \%)$.

\subsection{Pengaruh Faktor Gizi Terhadap Perkembangan Motorik}

Berdasarkan hasil penelitian didapatkan bahwa faktor gizi mempengaruhi perkembangan motorik pada balita usia 4-5 tahun, hal ini dapat dilihat pada tabel 3.11 tentang tabulasi silang antara faktor gizi dengan perkembangan motorik pada balita di TK Siswa Harapan, Ciliwung Surabaya menunjukan sebanyak 2 responden $(66,7 \%)$ memiliki faktor gizi kurang dengan perkembangan motorik suspect (meragukan). Menurut Ali (2003) kondisi gizi yang kurang, tentu akan sangat berpengaruh pada kemampuan dalam perkembangan motorik anak. Gizi yang seimbang adalah susunan makanan sehari-hari 
yang mengandung zat-zat gizi seperti karbohidrat, lemak, protein, vitamin, mineral, dan air dalam jenis dan jumlah sesuai dengan kebutuhan tubuh. Keadaan kurang gizi juga berasosiasi dengan keterlambatan perkembangann motorik. Keadaan ini dapat disimpulkan bahwa perkembangan motorik berhubungan erat dengan status gizi. Status gizi dapat dipengaruhi oleh beberapa faktor antara lain faktor konsumsi pangan, pola asuh gizi, psikologis, genetik.Gizi yang seimbang dibutuhkan oleh setiap manusia,terutama pada balita, karena dalam tahap perkembangan motorik balita sangat membutuhkan gizi yang seimbang dengan kualitas dan kuantitas yang tepat sesuai dengan kebutuhan gizi balita. Balita yang sering diberikan makanan bakso atau makanan instan, yang jauh dari kebutuhan gizi pada balita sehingga akan mempengaruhi perkembangan motorik pada balita tersebut.

Berdasarkan tabel 3.4 tentang karakteristik responden berdasarkan pekerjaan orang tua yaitu sebagian besar responden bekerja sebagai pegawai swasta sebanyak 12 responden (63,2\%). Menurut Notoatmodjo (2005) menetapkan bahwa pengalaman belajar dalam bekerja yang berkembang memberikan pengetahuan dan keterampilan profesional. Berdasarkan penelitian bahwa orang tua yang sibuk bekerja tidak mempunyai banyak waktu, sehingga kemungkinan orang tua jarang memasakan beraneka ragam makanan dan lebih sering memberikan makanan instan dari pada makanan olahan sendiri dan orang tua hanya berfikir bahwa balitanya harus makan tanpa mempertimbangkan kebutuhan gizi balita. Sehingga balita sering diberikan makanan bakso dan makanan instan lainnya, yang jauh dari kebutuhan gizi pada balita.

\subsection{Pengaruh Faktor Lingkungan Pengasuhan Terhadap Perkembangan Motorik}

Berdasarkan hasil penelitian didapatkan bahwa faktor lingkungan pengasuhan mempengaruhi perkembangan motorik pada balita usia 4-5 tahun, hal ini dapat dilihat pada tabel tabel 3.12 tentang tabulasi silang antara faktor lingkungan pengasuhan dengan perkembangan motorik pada balita di TK Siswa Harapan, Ciliwung Surabaya menunjukan sebanyak 2 responden $(66,7 \%)$ menggunakan pola asuh otoriter dengan perkembangan motorik suspect. Menurut Gerungan (2002) mengatakan bahwa pada lingkungan pengasuhan merupakan interaksi ibu dan anak sangat mempengaruhi perkembangan motorik anak.
Pola asuh otoriter merupakan pola pengasuhan anak yang bersifat pemaksaan, keras dan kaku di mana orang tua akan membuat aturan yang harus di patuhi oleh anak-anaknya tanpa mau tahu perasaan anak. Dalam hal ini maka anak menjadi penakut, pendiam, dan kepribadian lemah sehingga akan mempengaruhi perkembangan motorik pada balita.

Berdasarkan tabel 3.3 tentang karakteristik responden tentang pendidikan orang tua sebagian besar responden memiliki orang tua yang berpendikan SMA yaitu sebanyak 13 orang $(68,4 \%)$. Latar belakang pendidikan orang tua dapat mempengaruhi pola pikir orang tua dalam mengasuh balitanya baik formal maupun nonformal kemudian juga berpengaruh pada perkembangan motorik balita. Pendidikan orang tua yang tinggi membuat mereka (orang tua) jelas mengerti apa yang terbaik pada anak-anaknya. Dimana dalam pola asuh otoriter yang orang tua terapkan pada anakanaknya, mereka membuat berbagai aturan yang harus di patuhi.

Berdasarkan tabel 3.4 tentang karakteristik responden tentang pekerjaan orang tua sebagian besar bekerja sebagai pegawai swasta yaitu sebanyak 12 orang $(63,2 \%)$. Sebagian pegawai swasta tentunya tidak memiliki banyak waktu untuk balitanya, sehingga orang tua dalam mengasuh cenderung memberi aturan unttuk anak-anaknya yang harus di patuhi.

\subsection{Pengaruh Faktor Stimulasi Terhadap Perkembangan Motorik}

Berdasarkan hasil penelitian didapatkan bahwa faktor stimulasi mempengaruhi perkembangan motorik pada balita usia 4-5 tahun, hal ini dapat dilihat pada tabel tabel 3.13 tentang tabulasi silang antara faktor stimulasi dengan perkembangan motorik pada balita di TK Siswa Harapan, Ciliwung Surabaya menunjukan sebanyak 4 responden $(80 \%)$ stimulasi kurang dengan perkembangan motorik suspect (meragukan). Menurut Nursalam (2005) mengatakan stimulasi merupakan bagian dari kebutuhan dasar anak yaitu asah atau kegiatan merangsang kemampuan dasar anak umur 0-6 tahun agar anak dapat tumbuh dan kembang optimal. Setiap anak perlu mendapatkan stimulasi rutin sedini mungkin dan terus menerus pada setiap kesempatan. Dengan memberikan stimulasi yang berulang dan terus menerus pada setiap aspek terutama pada aspek perkembangan motorik berarti telah memberiikan kesempatan pada anak untuk 
berkembang secara optimal. Dapat diartikan bahwa stimulasi mempengaruhi dalam perkembangan balita. Dalam setiap ada kesempatan berinteraksi dengan balita maupun melakukan aktivitas, orang tua harus memberikan stimulasi secara terus menerus dan bervariasi kepada balita yang disesuaikan dengan usia perkembangan dan kemampuan balita.

Berdasarkan tabel 3.4 tentang karakteristik responden tentang pekerjaan orang tua dapat diketahui sebagian besar responden bekerja sebagai pegawai swasta yaitu sebanyak 12 orang $(63,2 \%)$. Menurut Luluk (2005) bahwa faktor pekerjaan orang tua adalah faktor yang berhubungan dengan aktivittas orang tua setiap harinya untuk memperoleh penghasilan guna memenuhi kebutuhan hidupnya. Dalam hal ini orang tua yang bekerja sebagai pegawai swasta tidak mempunyai waktu yang banyak dengan balitanya. Sehingga orang tua sering tidak mengajari balitanya menggambar, dan tidak menyediakan fasilitas permainan yang dapat merangsang perkembangan motorik pada balitanya, dan dari hasil ini tidak terjadi kesenjangan.

\subsection{Pengaruh Faktor Pengetahuan Terhadap Perkembangan Motorik}

Berdasarkan hasil penelitian didapatkan bahwa faktor pengetahuan tidak mempengaruhi perkembangan motorik pada balita usia 4-5 tahun, hal ini dapat dilihat pada tabel tabel 3.14 tentang tabulasi silang antara faktor pengetahuan dengan perkembangan motorik pada balita tahun di TK Siswa Harapan, Ciliwung Surabaya menunjukan pengetahuan baik dengan perkembangan motorik normal yaitu tidak ada responden, sedangkan pengetahuan kurang dengan perkembangan motorik normal yaitu 5 responden (38,5\%). Menurut Notoatmodjo (2005), pengetahuan merupakan hasil tahu dan ini terjadi setelah orang melakukan penginderaan terhadap suatu objek tertentu. Pengetahun orang tua memegang peranan penting dalam memberikan stimulasi kepada anak. Adapun faktor-faktor yang mempengaruhi pengetahuan adalah orang tua, jenis kelamin, umur, pendidikan, pekerjaan dan jumlah anak.

Berdasarkan tabel 3.1 mayoritas orang tua responden seorang ibu sebanyak 15 orang (78,9\%). Menurut Notoatmojo (2005), peranan ibu adalah pemberi rasa aman, sumber kasih sayang, pengatur kehidupan rumah tangga, dan pendidik bagi emosional. Kenyataannya pengetahuan ibu tentang perkembangan motorik pada balita usia 4-5 tahun kurang. Kurangnya

pengetahuan orang tua tentang perkembangan motorik pada balita usia 4-5 tahun dapat disebabkan karena banyak orang tua yang tidak mencari informasi. Informasi tersebut tidak didapatkan pada pendidikan formal, tetapi orang tua harus mencari sendiri.

Berdasarkan tabel 3.2 tentang karakteristik orang tua responden berdasarkan usia yang terbanyak adalah 31-35 tahun dan $\geq$ 36 tahun sebanyak 6 responden $(31,6)$. Menurut Notoatmojo (2005), usia mempengaruhi terhadap daya tangkap dan pola pikir seseorang. Semakin bertambah usia semakin berkembang pula daya tangkap dan pola pikir sehingga pengetahuan yang diperoleh semakin membaik. Dari hasil penelitian, usia ini tergolong usia dewasa seharusnya pengetahuannya lebih baik dan matang, tetapi kenyataannya pada usia tersebut pengetahuan mereka kurang. Hal ini kemungkinan disebabkan kurangnya keinginan orang tua untuk mencari informasi yang ada di sekitarnya.

Berdasarkan tabel 3.3 tentang karakteristik responden berdasarkan pendidikan orang tua yang terbanyak yaitu berpendidikan SMA sebanyak 13 responden $(68,4 \%)$. Menurut Wahid (2007) pengetahuan salah satunya di pengaruhi pendidikan, dimana semakin tinggi tingkat pendidikan seseorang semakin mudah menerima informasi, pada akhirnya makin banyak pola pengetahuan yang dimilikinya serta mampu dalam menerapkan apa yang diketahuinya. Dalam penelitian ini kemungkinan orang tua sudah mendapatkan informasi tentang perkembangan motorik, tetapi tidak tahu cara mengaplikasikan dalam kehidupan sehari-hari.

Berdasarkan tabel 3.4 tentang karakteristik responden berdasarkan pekerjaan orang tua yaitu sebagian besar responden bekerja sebagai pegawai swasta sebanyak 12 respondeen $(63,2 \%)$. Menurut Notoatmodjo (2007) menetapkan bahwa pengalaman belajar dalam bekerja yang berkembang memberikan pengetahuan dan keterampilan professional. Berdasarkan penelitian bahwa orang tua sibuk bekerja sehingga tidak memahami dan tidak fokus dalam memberikan perhatian pada balitanya. Seharusnya orang tua memahami, memperhatikan, dan mencari informasi tentang perkembangan motorik pada balita.

\section{Simpulan}

Berdasarkan analisis dan pembahasan di atas maka dapat disimpulkan bahwa:

\subsection{Faktor Gizi}


Faktor gizi mempengaruhi perkembangan motorik pada balita usia 4-5 tahun di TK Siswa Harapan, Ciliwung Surabaya.

\subsection{Faktor Lingkungan Pengasuhan}

Faktor lingkungan pengasuhan mempengaruhi perkembangan motorik pada balita usia 4-5 tahun di di TK Siswa Harapan, Ciliwung Surabaya.

\subsection{Faktor Stimulasi}

Faktor stimulasi mempengaruhi perkembangan motorik pada balita usia 4-5 tahun di TK Siswa Harapan, Ciliwung Surabaya. 5.4 Faktor Pengetahuan

Faktor pengetahuan tidak mempengaruhi perkembangan motorik pada balita usia 4-5 tahun di TK Siswa Harapan, Ciliwung Surabaya..

\section{Saran}

6.1 Bagi TK Siswa Harapan, Ciliwung Surabaya Agar selalu mengadakan kegiatankegiatan yang dapat menstimulasi perkembangan pada balita khususnya perkembangan motorik seperti kegiatan olah raga, menggambar, dan guru memberitahukan hasil evaluasi perkembangan motorik pada orang tua sehingga orang tua dapat mengetahui dan meningkatkan perkembangan motorik balita. Serta bekerja sama dengan instansi kesehatan seperti puskesmas untuk memantau perkembangan motorik pada balita dan memberikan penyuluhan / seminar secara bekala kepada orang tua tetang perkembangan motorik.

\subsection{Bagi Stikes William Booth}

Perlu memperbanyak literatur tentang keperawatan anak dan menekankan cara memberikan gizi, stimulasi pada balita, menerapkan pola asuh yang benar, dan pengetahuan tentang perkembangan motorik sehingga mahasiswa dapat turut memberikan informasi secara jelas dan dapat melakukan pengapdian kepada masyarakat tentang perkembangan motorik pada balita.

\subsection{Bagi peneliti selanjutnya}

Diharapkan penelitian ini dapat dijadikan sebagai sumber informasi dalam penelitian lebih lanjut tentang perkembangan motorik pada usia 4-5 tahun dengan jumlah responden yang lebih banyak.

\section{DAFTAR PUSTAKA}

Alimul, A. 2010. Metode Penelitian Kebidanan. Jakarta: Salemba Medika.

Ali Khomsan. 2003. Pangan dan Gizi untuk kesehatan. Jakarta: PT. Rajagrafindo

Andriana, Dian. 2011. Tumbuh Kembang dan Terapi Bermain Pada Anak. Jakarta: Salemba Medika.

Arikunto, Suharsimi. 2006. Prosedur Penelitian Suatu Pendekatan Praktik. Jakarta: Rineka Cipta

Depkes RI. 2005. Pedoman Pelaksanaan Stimulasi, Deteksi dan Intervensi Dini Tumbuh Kembang Anak Di Tingkat Pelayanan Kesehatan Dasar. Hal : 4, 7, $11,45-53$.

Fida, Maya. 2012. Pengantar Ilmu Kesehatan Anak. Jogjakarta: D-Medika

Gerungan, W.a, 2002. Psikologi Sosial. Bandung: Eresco

Hurlock, E. 1998. Perkembangan Anak jilid 1. Jakarta: Erlangga

IDAI (Ikatan Dokter Anak Indonesia). 2005. Tumbuh Kembang Anak dan Remaja Edisi ke-1. Jakarta: Sagung Seto

Ilahi, M. Takdir. 2013. Quantum Parenting : Kiat Sukses Mengasuh Anak Secara Efektif dan Cerdas. Jogjakarta: Kata Hati

Ira, Petranto. 2005. Pola Asuh Anak. http://www.polaasuhanak.com diunduh tanggal 1 Februari 2015 jam 09.00 WIB.

Lipkin, PH. 2009. Development-Behavior Pediatrics. Edisi ke -4. Philadelphia: Saunders.

Lismadiana. 2014. Peran Perkembangan Motorik Pada Anak Usia Dini. http://www.perkembanganmotoriklisma. com diunduh tanggal 03 Desember 2014 jam 8.49 WIB.

Mahayati, Lina. 2014. Studi Tentang FaktorFaktor Yang Mempengaruhi Pertumbuhan Dan Perkembangan Pada Balita Di Desa Pengalangan RW 03 
Menganti Gresik. Jurnal Keperawatan. 3 (1:55-60).

Maritalia, Dewi. 2009. Analisis Pelaksanaan Program Stimulasi, Deteksi Dan Intervensi Dini Tumbuh Kembang (SDIDTK) Balita Dan Anak Pra Sekolah

http://www.PuskesmasKotaSemarang.co m diunduh tanggal 06 Agustus 2015 jam 14.00 WIB

Nursalam. 2005. Asuhan Keperawatan Bayi dan Anak. Jakarta: Salemba Medika.

2013. Metode Penelitian Ilmu Keperawatan. Edisi 3. Jakarta: Salemba Medika.

Notoatmodjo, Soekidjo. 2005. Metode Penelitian Kesehatan. Jakarta: Rineka Cipta.

2012. Metode Penelitian Kesehatan. Jakarta: Rineka Cipta.

Santrock. 2011. Masa Perkembangan Anak. Edisi 11. Jakarta: Salemba Humanika.

Sugiyono. 2013. Statistika untuk Penelitian. Bandung: Alfabeta.

Sulistyawati, A. 2014. Deteksi Tumbuh Kembang Anak. Jakarta: Salemba Medika.

Supartini, Yupi. 2014. Buku Ajar konsep Dasar Keperawatan Anak. Jakarta: EGC.

Suryawan A, Narendra M.B, 2010. Penyimpangan Tumbuh Kembang Anak. RSUD Dr. Soetomo Surabaya.

Septiari, B. 2012. Mencetak Balita Cerdas dan Pola Asuh Orang Tua. Yogyakarta: Nuha Medika.

Setiadi. 2007. Konsep dan Penulisan Riset Keperawatan. Yogyakarta: Graha Ilmu.

Soetjiningsih, Ranuh. 2013. Tumbuh Kembang Anak Edisi ke-2. Jakarta: EGC. 